\title{
Teaching Evolution in Muslim Countries: Is Constructivism a Solution or a Threat?
}

\author{
Özgür TAȘKIN*
}

\begin{abstract}
Since the turn of this century, constructivism has dramatically influenced science education and, particularly in Muslim countries, the teaching of evolution. This influence came about gradually. After the 1980 's, Muslim graduate students studying Education in Western universities have been taught constructivism both as a theory of learning and a philosophy, more specifically, as an epistemological theory. This has impacted these students' views of the nature of science, scientific argumentation, multiculturalism, and the function of democratic values and practices in education. The scope of this influence raises a number of serious questions: Has constructivism introduced a mode of reasoning into science and science education that is foreign to, and even anathema to, scientific discourse? Why does almost every science education research paper suggest or imply negotiation with clergy and religious NGOs? Such questions are discussed in the present paper. To answer these questions, this paper examines in the context of Enlightenment and secularism theoretical frameworks, the methodologies, and suggestions regarding the teaching of evolution in Muslim countries.
\end{abstract}

Keywords: Teaching Evolution, Science Education, Muslim Countries, Constructivism, Enlightenment, Neoliberalism

\section{Müslüman Ülkelerde Evrim Öğretimi: Yapılandırmacılık Çözüm mü Tehdit mi?}

\begin{abstract}
Öz: Yeni yüzyıla girişle birlikte, yapılandırmacılık bilim eğitimini ve özellikle de Müslüman ülkelerde evrim eğitimini etkisi altına almıştır. Bu etki adım adım gelmiştir. Özellikle 1980 sonrası Batıda eğitim alanında öğrenim gören Müslüman lisansüstü öğrencilerine yapılandırmacılık hem bir öğrenme kuramı, hem de felsefi bir yaklaşım olarak, daha net bir anlatımla ise bir epistemolojik kuram olarak öğretilmiştir. Bu olay öğrenim gören öğrencilerin eğitimdeki bilimin doğası, bilimsel argümantasyon, çok kültürlülük, demokratik değerlerin işlevselliği ve uygulamaları hakkındaki görüşlerini etkilemiştir. Bu çalışma bazı sorulara odaklanmıştır: Yapılandırmacılık, bilim ve bilim eğitimine bilimsel söyleme yabancı, hatta son derece ters bir akıl yürütme mi getirdi? Neden, nerede ise tüm bilim eğitimi araştırma yazıları din adamları ya da dini sivil toplum kuruluşları ile uzlaşmayı öneriyor ya da ima ediyor? Bu ve benzeri sorular bu araştırmada tartışılmıştır. Bu soruları yanıtlamak için, araştırma Müslüman ülkelerdeki evrim eğitimi ile ilgili önerileri ve yöntemleri Aydınlama ve sekülarist kuramsal çerçeveleri içinde değerlendirmektedir.
\end{abstract}

Anahtar Sözcükler: Evrim Eğitimi, Fen Eğitimi, Müslüman Ülkeler, Yapılandırmacılık, Aydınlanma, Neoliberalizm

* Ondokuz Mayis University, School of Education, The Department of Mathematics and Science Education, Samsun, Turkey, e-posta: otaskin@omu.edu.tr, ORCID: https://orcid.org/0000-0002-5530-7312 
While in the natural sciences the debate over the question of creation and the theory of evolution (TOE) is settled, in education attempts at introducing creationist agendas into curricula persist and even intensify. In their chapter titled "Rejecting Materialism: Responses to Modern Science in the Muslim Middle East", Edis and BouJaoude (2014) outline the oppressive situation of pro-evolutionists in Muslim countries. While in literature there is an abundance of references to, for instance, the Lysenko case from the 1930s (e.g., Lederman, 1995) as an example for how scientific thought is subjected to an ideological agenda, the struggle against creationism in such Muslim countries and its difficult stance have hardly been observed and analyzed in research. Not only is there a dearth in research on how science curricula have been subject to religious agendas in Muslim countries for many years, there is, on an institutional level, hardly any organized defense of the teaching of evolution against the anti-evolution movement. Even in Turkey, constitutionally secular country there are very few conferences or organizations that explicitly support the teaching of evolution, with the exception of some conferences at a number of metropolitan universities. One of these exceptions is a progressive group titled University Council Association (UCA) which organizes the Evolution, Science, and Education Symposiums every two years in Turkey since 2006. UCA have brought widely-known key-speakers to these meetings: Richard Dawkins, Douglas Futuyma, and Andrew Berry. Other presenters, different areas from anthropology to sociology have also showed the interaction between biology and social sciences. Beyond this bi-yearly conference, it is almost impossible to find another conference. As Alexander and Welzel (2017) imply this situation is typical for the countries those do not internalize emancipatory values.

Also, in Western countries, the TOE is subject to ideological battles, and anti-creationist agents can pursue their agendas often with success. Thus, in the US, particularly in states with conservative Republican governments, such as Tennessee and Louisiana, science teachers may present creationism and Intelligent Design (ID) as equally valid as the TOE. Yet, even in Darwin's own country the TOE is on occasion successfully eliminated from curricula. For instance, the Truth in Science Foundation, whose leader has openly supported creationism and ID, has managed to be classified as a state school in the UK to gain access to state funding. This happened, not without irony, under a Labour government, whose Prime Minister, Tony Blair, called concerns about this decision that were voiced in the press unwarranted and exaggerated (Williams, 2008). It thus appears that also liberal worldviews offer creationist agendas a chance to insert themselves into school curricula. Liberal educators have often been led by their ideal of democratic education to underestimate the specific role of religion in educational settings especially in Muslim countries.

The present paper sets out to show that the constructivist paradigm in science education has been particularly ineffective in stemming the attempts at implementing creationist agendas and, due to a problematic interpretation of democratic education as its leading ideal, has even been complicit, in such attempts. From the vantage point of constructivism, reactionary tendencies such as creationist agendas in educational settings are uncritically accepted under the guiding influence of a problematic interpretation of constructivist key concepts such as cultural setting, pluralistic, and democratic education. How this has happened in India has been well documented by Meera Nanda (2003). Both indigenous and foreign relativists have been allies.

In this context, this paper discusses

1- previously conducted constructivist studies about teaching evolution in Muslim countries. These studies often draw an inaccurate picture of the by employing Islamic terminology in a misleading way, distorting theoretical frameworks, and research methodologies with vague demographic variables such as race instead of socioeconomic level.

2- the particular dynamics of the interaction between Western liberal scholars and scholars with Islamic creationist agendas. This concerns Western scholars' perspectives on teaching evolution in Muslim countries, but also Western institutional aspects, such as grant support and data collection, are critically investigated. 
To do so, an exhaustive literature review was conducted, and studies written in English were selected from the most prestigious peer-reviewed journals in the area, even though some studies can be found in other languages. The selected authors, journals, and studies have a strong influence in science education. At least one of the researchers authoring a study is familiar with Muslim educational settings and/or has roots in a Muslim culture. However, I would like to point out that the present research does not aim at defining or questioning a researcher's ethnic identity or religious affiliation. Rather, the present paper focuses on the work of specialists on science education in Islamic cultures and the use these specialists make of constructivism in specifying the status of the TOE in science education.

\section{Theoretical Framework}

Matthews $(2015$, p. $757 ; 2018)$ critically emphasizes that the Western science-education community is often ignorant about reactionary movements in Muslim countries. Muğaloğlu's paper (2014) outlines how constructivism is turned into a misleading agent in Muslim countries. In the framework of Enlightenment and secularist codes, she discusses the aforementioned intentional or unwitting complicity of constructivism with the introduction of religious and scriptural fundamentalist thought into science teaching. Of particular concern in this context is the anti-emancipatory tendency that thus finds support in constructivism. From a Marxist, social-justice perspective, constructivist research fails at promoting emancipatory thought since it has embarked on an equity discussion that has made important socioeconomic distinctions such as class invisible and has diminished the emancipatory dimension of education by legitimizing a state of ignorance rather than offering ways out of it - the term alternative conception has in science-education literature widely replaced that of misconception (Gilbert \& Watts, 1983), in effect rendering proven scientific discourses, such as the TOE, indistinguishable from metaphysical concepts and outright lies, nowadays called 'alternative facts', which in the form of climate-change skepticism now threaten to shape policy and endanger the entire planet's ecosystem. Those who are most disadvantaged by this corrosion of science in science education are, not incidentally, those who are underprivileged. According to White (1980), "The process of domination by ruling class is not only material and physical but also cultural." Constructivism supports an educational setting anathema to emancipation with some of its key concepts: Cultural milieu, individuality, religion blended value education, multiculturalism and so on are too often used to cater to a neoliberal ideology.

In the light of this argumentation, this paper's subject can be analyzed both along the axis of constructivism and neoliberalism as well as with reference to the tenets of Enlightenment and secularism. The paper choses the latter framework, but also makes reference to the former.

\section{Back to basics: Constructivism, secularism, neoliberalism and reactionary}

There are numerous definitions of constructivism. The most wide-spread definition of the term constructivism is that it denotes a school of thought that considers knowledge the result of active construction by individuals and/or a society and that knowledge construction as a process is based on social negotiation (von Glasersfeld, 1995). This definition is necessarily blind to the kind of cultural setting in which knowledge is constructed, i.e. to the question if construction and negotiation take place under democratic conditions in open societies or under the conditions of autocratic regimes. While definitions are not evaluations, science education research has too often contented itself with the insight that knowledge is constructed and has not engaged in critically assessing the conditions of educational settings (Matthews, 2021). Phillips (1995) discusses epistemological, sociopolitical, and educational (pedagogical) aspects of constructivism and claims that constructivism is a secular religion. However, neither is the analogy between constructivism and religion particularly elucidating nor can the modifier 'secular' be rightly applied to constructivism in an Islamic educational setting. Contrary to Phillips definition, constructivism opens the door toward either solipsism or pseudoscientific thoughts. Rather, it may be used as a pragmatic tool by fundamentalists. Multi-layered definitions of the terms used in this paper can also be found in Muğaloğlu (2017).

The term secularism is perceived and applied differently in each country depending on cultural codes. In this text, secular science is considered as scientific discourse without any discursive intersections with religion. 
This means that in secular science religious doctrine or spiritual texts are not accepted as an argumentative support. Thus, the present text emphasizes the qualities of science that Matthews considers to be "... tenets of the European Enlightenment tradition, and in particular its universalist, naturalist and secular commitments..." (Matthews, 2015, p. 270).

This paper considers constructivism in its affinity to Neoliberalism. According to Jubas, "The ideology of neoliberalism attributes responsibility and blame for outcomes to the individual." (Jubas, 2012, p. 26). Neoliberalism can generally, and also in an educational context, be defined as an ideology that privileges individual good over public good. The concept of good differs within the context of the Enlightenment. While to Locke, the individual good has priority, Rousseau considered the public good as a precondition to the individual good and thus as more important. Both Neoliberalism and constructivism focus on individuality and thus on the individual good. In contrast, the present paper draws on Rousseau's understanding of good.

The term reactionary is defined in the Cambridge dictionary as "Opposed to change and progress or favouring a return to things as they were.". The definition leaves unspecified what the rejected ideas or changes are. For the purpose of this paper, reactionary is defined as an ideological opposition to progressive ideas which, in this paper, include scientific observations and conclusions that go against the grain of ideological beliefs. While the TOE may not be considered as progressive by many individuals who take it for granted, it still is progressive in a context in which it collides with religious beliefs (and, I may add, with vested interests). The term reactionary may reverberate with some other concepts such as fascism, racism, sexism, unscientific (pseudoscientific), religious obsessive, non-secular, conservative, politically right-wing, believing in a free-market economy and privatization and so on. More synonyms can be found in Collins and Oxford Dictionary. Castéra and Clément's study (2014) is a good example to reevaluate the aforementioned term in different social contexts based on better citizenship attitude.

\section{Research on Teaching Evolution in Muslim Countries}

The first journal, Evolution, Education, and Outreach primarily focused on teaching and learning TOE has been appearing since 2008. In the first issue of the journal edited by Niles and Gregory Eldredge, Gregory lays out the term evolution as theory, truth, and disjunction in life (Gregory, 2008). The term disjunction represents a variety of things: the refraction between science and pseudoscience; the endless, intensifying struggle between the Enlightenment and reactionary movements, especially those under the dominance of neoliberal ideology. For approximately the last 30 years, research on problematic issues in teaching and learning the TOE has generally focused on attitude and content knowledge.

At the beginning of the 1990s, with the publishing of the National Science Education Standards, the term the Nature of Science (NOS) surfaced. The concept denotes that science is always tentative and that its results are never final. While the concept has its merits, it can also exert a corrosive influence on the reception of scientific thought. In 1998, a book appeared that brought the two concepts, evolution and NOS, into close contact; its title was Teaching about Evolution and the Nature of Science (National Research Council [NRC], 1998). While this book intended to support the teaching of evolution as a way to gain a more thorough understanding of the scientific process, the combination of concepts in its title points to a potentially damaging dynamic. Muğaloğlu and Erduran (2012) emphasize that prospective science teachers refer to characteristics of NOS in order to justify their positions about teaching evolution and/or ID. For instance, one of the prospective science teachers who argued for teaching ID as an alternative to evolution theory justified his/her position with the tentativeness of theories in science. On the other hand, another prospective science teacher argued that ID is not acceptable in science since it is not testable. The first case should be a warning to science educators that either these "Prospective science teachers do not have a clear understanding of contemporary NOS views or these aspects of NOS are not sufficient to enhance prospective science teachers' appreciation of evolution." (Muğaloğlu \& Erduran 2012, p. 105). At this point, “Whose nature of science?" (Alters, 1997) is a good question: Alters shows that there is not one NOS. It can be concluded that as long as other codes privileging the cultural setting such as multicultural science, indigenous knowledge, viability, tentativeness, etc. are considered from a constructivist perspective as sharing in the NOS, constructivism may not be considered as progressive but, 
rather, as a pathway to an unscientific and possibly reactionary worldview. It is widely known that the epistemology of constructivism is rooted in pragmatism and relativism. Its epistemology is considered weak (Herron, 2008; Irzik, 2001) and dependent on the cultural-setting argument.

\section{Influence of Constructivism on Research Methodology}

When constructivism started to dominate most educational settings, it also happened research methodology. In quantitative research, Western researchers, especially in the USA, in the area of science education begun to use ethnicity as one of the demographic variables while ignoring the political affiliation and socioeconomic status (SES) of participants. Many times, as a journal reviewer, I could not find these demographic variables and asked the author(s) to state the reasons for their omission. The following two reasons emerged: either human subject committees did not allow the researchers to collect data on these variables or the researchers ignored them on purpose themselves. However, there should be some rationale behind disregarding these variables. It is obvious that if researchers have defined SES of participant based on even the Weberian way, they should point out sociologically problematic parameters such as low income, conservativeness, orthodox religiosity, and inequality in education. Instead, they have used demographic variables such as race. This methodological biased or corrupted area is not limited to quantitative approaches. It is possible that researches have shunned SES because they fear that they suffer setbacks in professional opportunities, such as having papers rejected or grants denied.

On the other hand, qualitative research techniques have created, in a postmodernist environment, a flexible zone for Muslim science educators, and this group has mostly been using this approach. There might be three reasons why Muslim science educators have this tendency. First, it does not allow researchers to generalize their findings. This creates a blind spot in that it makes it possible for Muslim science educators not to uncover problematic areas such as the Islamization of science by way of constructivism or the place of women in science education in the context of class theory. Second, it is almost impossible to conduct research on controversial topics via surveys because of regulations in Muslim countries and even in the USA (see Good, 2003). This is another excuse mechanism for covering up the real social ambiance in school settings. Third, microstudies allow researchers a chance to use codes of constructivism, such as different views, conceptual change in individuals, etc., rather than codes that would make social problems such as class consciousness or reactionary movements visible. This might allow Muslim science educators to swim in the mainstream. This is also part of the conceptual change in science, here particularly in research methodology, that Kampourakis and Nehm (2014) have outlined.

\section{Theoretical Framework: Distorted Suggestions via Constructivism}

Most of the studies have been based on the notion of conceptual change in an individual. Obviously, using individual characteristics has been a pragmatic technique to atomize society on behalf of a misapplied notion of diversity ${ }^{1}$. Thus, an oppressive social ambiance in many Muslim countries has been deemed as cultural milieu and has thereby been normalized by postmodernist science educators. With only a few exceptions, data analyses are built upon constructivism. I would like to show some robust evidence from research papers by experts in this area. Hokayem and BouJaoude (2008, p.398) state that:

\footnotetext{
The empirical studies discussed above reveal the importance of beliefs in understanding or accepting the theory of evolution. This leads one to give more thought to the qualitative studies that have attempted to describe and understand the relation between personal beliefs and the perception of science in general and the perception of the theory of evolution in particular. Those studies adopt a sociocultural perspective as a theoretical underpinning that acknowledges that the construction of knowledge is influenced by the individual's ideas that are shaped by social and cultural factors. This implies that religious beliefs, for example, cannot be treated as misconceptions but have to be included as part of an individual's 'cultural milieu' that requires detailed description and analysis rather than modification.
}

They follow up with a rhetorical question in a constructivist vein that blurs the lines between science and religion (p. 411):

\footnotetext{
${ }^{1}$ The author personally believes in the power of diversity. However, it does not mean that on behalf of diversity a reactionary movement and pseudoscience will be supported.
} 
The question now becomes: if the basis of science depends on 'faith' in the fundamentals, then how 'faith' in other ideas could be dismissed from the classroom? This is why Cobern and Aikenhead (1998) emphasize the importance of involving beliefs while leaning [sic!] science. According to them:

Because learning is about making meaning within a cultural milieu of a particular student, several questions must be asked. Within a cultural milieu of a particular student, what knowledge is important? What knowledge is meaningful? How does scientific knowledge relate to a students' cultural milieu? (Cobern and Aikenhead, 1998, p. 39).

Certainly, Hokayem and BouJaoude's suggestions are based on pro-constructivist arguments by Cobern and Aikenhead. What they propose is that science educators, whether Western or Muslim, who go to Lebanon, Afghanistan, Iraq, etc. to teach evolution, are not supposed to teach students in a progressive, enlightened mindset. Instead, they should find out what knowledge is important for students based on their cultural milieu and replicate this knowledge masked as science. Thus, pseudoscientific, mystic, superstitious thoughts or religious beliefs are not to be considered as misconceptions but as fully legitimate parts of social culture. Those enthusiastic about this approach may find other terms for it, such as border crossing (Aikenhead, 1996). Yet, don't Muslim societies deserve better than this?

BouJaoude et al.'s (2011) study shows that even many years of studying, and teaching, biology has not had any transformative influence on Egyptian biology professors' mindset. They still hold pseudoscientific thoughts. The first key word of the paper is alternative conception. BouJaoude, Wiles, Asghar, and Alters (2011) conducted a similar comparative study in Lebanon and Egypt with high school students. The results show that Druze students are more in favor of the concept of evolution than Muslim students. Even though the authors prefer to use the term misconception, again there is no reference to non-secular science education and its detrimental effects.

In another study, Asghar (2013) compares Muslim science educators' perceptions about evolution and teaching in Canada and Pakistan. One of the research questions in the study is aimed at identifying the differences between secular and religious contexts. In her conclusion, Asghar suggests to make improvements to training, content, and pedagogical knowledge. Even though her suggestions are more progressive than the above research, she misses the main problem, and, as a result, her work only differs in nuance from those discussed above.

Similarly, Deniz, Donnelly, and Yilmaz's (2008) research suggests to turn to constructivism as an approach to teaching evolution in Turkey - and thereby imply, or even pretend, that evolution has had the status of a worthwhile scientific subject for the last 30 years in Turkey. According to the authors, the approach to teaching evolution has been too mechanistic and, therefore, students have not been able to gain an understanding of the TOE. Given the highly perfunctory way that evolution has been taught in Turkey, the authors' diagnosis is a red herring.

Deniz, Çetin, and Yılmaz (2011) show that most students are in favor of being taught both creationism and evolution. They suggest that student rejects biological evolution because of a poor understanding of modern science. To remedy this problem, the authors propose the NOS as a helpful tool. However, if rejection of evolution is based on religious beliefs, a further discrediting of science does not appear to result in successful science education. It should be noted that almost no Muslim science educator suggests an emphasis on secular science as an appropriate means. Rather, they propose ambiguous pathways that avoid confronting the political and social conditions that lead to ineffective science education and possibly aggravate the problem rather than solving it.

Interestingly, when The Scientific and Technological Research Council of Turkey (TUBITAK) censored the special cover book in memory of Darwin (Anonymous, 2009), one of the journalists interviewed Yilmaz, who is the one of the authors of the article mentioned above. In this interview, Yllmaz stated:

“...People who would like to present evolution as law, as a matter of fact, use it for their materialist and atheist ideas. They can publish this in their own journals ... the theory of evolution or Darwinism is far away from science based on hypothesis ..." (Sak, 2010, October 9). 
It is, however, not quite clear what Yllmaz considers proper science. After all, before the above quoted comment, the author had claimed that Adam was 30 meters tall and lived with dinosaurs (Kahvecioglu, 2012). This and other claims find a place in a book entitled Towards Alternative Biology (Yılmaz and Uzunoğlu, 1995). Another book entitled Evolution: Science or Ideology was also published in three different languages. In his book, Yilmaz says:

"Most evolutionists claim that the idea of evolution is a theory, but for some of them it is almost a definite law. Indeed, evolution is an idea that cannot go beyond being a hypothesis in this form... their theory is left incomplete and insufficient." (Yilmaz, 2008, p. 8).

This does raise some questions about the studies conducted in 2008 and 2011, of which he was a co-author. In particular, it has to be asked what motivates Yilmaz to support constructivism. Does he adhere to a relativist epistemology of constructivism? Not surprisingly, one of the American authors of one of the above studies makes almost the same cliché suggestions, but appears to add some nuance: Do not cross the borders of students' values (see Borgerding, Deniz, \& Anderson, 2017; Donnelly, Kazempour, and Amirshokoohi, 2009). Similar recommendations can be found in literature.

On the other hand, Peker, Cömert, and Kence (2010) claim that there is almost no scientific teaching of evolution at the undergraduate level in Turkey except at some metropolitan universities. They are exception. Contrary to Peker and coworkers' findings, Asghar, Hameed, and Farahani (2014), in their evaluation of biology textbooks, create the wrong impression that evolution is regularly covered in science teaching in Turkey. Even though they call their research a snapshot, they too need to be held to certain standards. I would like to know how they came to the conclusion, in particular how the authors have got their information on Turkey and how many lines of text regarding evolution they found in the textbooks they evaluated. Interestingly, Hameed (2015) considers Turkey as a radically secular country without basing this in sociological information and calls with his coworkers (2014) this ambiguous ambiance as Arab Spring instead of turmoil. Are these definitions to be considered as a snapshot or as misleading information?

Aroua, Coquide, and Abbes (2010) openly discuss the difficulties of teaching the TOE in Tunisia and discuss necessary epistemological changes. They consider themselves lucky because teaching the TOE is not forbidden. Pierre Clément is one of the most important researchers in this area and a prominent science educator in continental Europe. According to Clément (2015), Muslim teachers' conceptions of evolution change depending on where they live and other sociological and historical dimensions. Dowd (2003) and Taşkın (2014) have also suggested this relation.

Mansour (2008) stresses the importance of Egyptian teachers' personal religious beliefs in the context of social-cultural constructivism. Not surprisingly, Mansour offers the following option for science educators:

"I agree with the position that compatibility is needed between religious education and science education. In cultures where religion has a major influence on people's lives the development of science curricula should be made in a partnership between science educators and religion scholars, especially with regard to socioscientific issues associated with religion. This process would provide opportunities to challenge teachers' personal religious beliefs, to introduce appropriate perceptions of religious attitudes, and to leave the door open for different views and different understandings." (Mansour, 2010, p. 138)

To Mansour, different understandings should be considered as part and parcel of the science teaching process. As Jenkins (2001, p. 157) states, constructivism promotes active learning but not per se progressive education. However, progressive education is in no contradiction to the active involvement of students. Basically, Mansour implies that students should be left alone in their cultural milieu. This attitude appears to be part of a tendency to pseudo-science.

In 2011, Mansour investigated science teachers' views regarding science and Islam from an Islamic perspective (2011). Mansour's paper contains two misleading points. The first one is the definition of ijtihad. The second one is the categorization of utterances based on Ian Barbour's classification.

The definition of the term ijtihad should be considered in three-fold. First, Mansour defines it as "doing one's best in searching and making up one's mind logically." According to Al-Hayani (2005, p. 567), ijtihad 
"Means to exert effort and apply knowledge in studying the precepts set in the Qur'an and the Sunnah of the Prophet to form an independent judgement on a legal question." This searching process is proper according to the Qur'an if it is conducted not haphazardly or based on findings from another culture. This means that interpretations have to be based on scripture.

Second, ijtihad is not allowed to all Muslims as Mansour implies in his paper. Who wishes to embark on the ijtihad process should have basic qualifications, such as understanding Arabic. This means that individuals lacking Arabic language skills have no right to make up their mind about a religious question on their own. Qualified individuals are called Ulema ${ }^{2}$ and only these people have a right to decide whether or not something is proper in the context of Islamic social life. It is unfortunately also inaccurate to assume that questions of social conduct and scientific questions are of different categories in Islam. Scientific endeavors might create problematic issues. Yet, Ulama can hardly be expected to come to sound conclusions as their agreement needs to be based on the Qur'an and other Islamic religious sources ${ }^{3}$. This means that every negotiation between science and religion must itself take place on religious grounds. Regardless, Muslim science educators deem this concept as an appropriate element of $21^{\text {st }}$ century science education and thereby shortchange the chances of students in Muslim countries to receive proper science education.

Third, as far as I know ijtihad gate was closed, particularly in the Sunni world, after the $12^{\text {th }}$ century. AlHayani (2005, p. 568) locates this closing in the mid-13 ${ }^{\text {th }}$ century. At least, debates about the current status of ijtihad are continuing. According to Hallaq (1986), the gate has not been closed. However, Halliday (2002), from the London School of Economics, contends that the "conventional Sunni position is that the gate of ijtihad was closed centuries ago." The Princeton Encyclopedia of Islamic Political Thought says "It has often been said that in Sunni Islam, the gate or door of ijtihad was closed in the distant past - ca. 900 or 1000 - ..." (Bowering, 2013, p. 244).

In any case, Mansour should have clarified this because his argument leads his readers to the assumption that most people have the right to conduct ijtihad and that this right is based on objective rules. In excluding vital information about ijtihad, Mansour's argument is quite misleading. The ulema have the right to give an opinion about anything based on the Qur'an without any expertise in the subject field. However, Mansour proposes to negotiate with clergy in matters scientific. If Galileo's writings had been negotiated with the Church, the reader might still think that the Sun circles around the Earth.

The last problematic issue concerns the categorizations of the participants' utterances, which is often confusing if not incorrect. For instance, the following statement of a participant is categorized under compatibility of science and Islam:

I agree that scientific knowledge is the truest form of knowledge in the field of natural phenomena in cases where there is no discrepancy (conflict) with the Islamic religion. Also, science continuously comes to show clearly what we don't understand about religion. (T/Hend, questionnaire)

The participant clearly says that scientific findings are only true as long as they do not contradict religion. Similarly, confusing categorizations have been made with many utterances in Mansours paper. These, together with his incorrect thesis that teleology is a central part of Lamarckism (Kampourakis and Nehm, 2014, p. 382), lead to the question if the proclaimed conceptual change in science is based on data distortion.

Mansour highlights another point: Distrust of Western colonizers. He claims that distrust might be the reason of unscientific thoughts in Muslim teachers because what Western scientist or societies bring is secular and thus anathema to Islamic values. To support this idea, he draws inspiration from other proponents of constructivism, Aikenhead and Ogawa. Mansour states that:

\footnotetext{
"Another possible cause of the anti-Eurocentric sciences argued by Aikenhead and Ogawa (2007) is the nature of the conservative culture of school science that is not conducive to teachers rising above the scientific method, realism, and positivism. As a result, school science generally fails to inform students about the authentic Eurocentric sciences that permeate their everyday lives." (Mansour, 2011, p. 304).
} 
Mainly, the notion of indigenous science is offered as a remedy.

Mansour also considers the participants' thoughts in the context of the NOS and of an Islamic perspective of science as naïve. He finds that Muslim science teachers and/or students are not comfortable with Eurocentric science classes. Interestingly, Mansour sometimes supports socio-scientific arguments with opinions of the clergy and verses from the Qur'an. He supports this practice as follows: "In the Qur'anic view, God is the Creator and Sustainer of the universe. He has created everything in measure and has decreed for it a telos..." (Mansour, 2010, p.134). I do not consider this kind of support as valid even though many postmodernist scientists may think otherwise. Ironically, Mansours practice leads to the question whether quoting the Pope to support a scientific argument is Eurocentric - given Mansour's practice, he would have to answer this question with a 'no'.

And why shouldn't he. After all, Mansour accepts every supportive argument - whether or not scientific - offered to him by Westerners as long as these arguments come from a non-secular camp of Western society. Another problematic issue in Mansour's writings is his need to convince the readers that Islam is not against science. Incidentally, Islam does not need Mansour's help. To support this idea of Islam as a force of Enlightenment, he cites verses from the Qur'an. Is this a sign that he follows in Muzaffer Iqbal's path? Basically, Iqbal observes that the Qur'an treats many scientific issues, including the origin of the cosmos and of life (Guessoum, 2008). Mahner and Bunge, who clarify Christian science educators' paradoxes in their paper, point out that in history "many religionists have turned 'liberal' " (1996, p. 108) as a pragmatic behavior.

To come back to the observation above that the faultline does not run between Western and Muslim societies but between secular and non-secular camps, there is indeed a dialogue between religions, and this dialogue is directed against progressive education (Shapiro, 1999). Liberals and conservatives have seized on constructivism and turned the educational system into a reactionary setting. Good and Shymansky (2001) show how teaching the TOE is rejected in the name of multiculturalism, i.e., of a quite liberal concept. Basically, the concepts of cultural milieu and multiculturalism have been used as arguments supporting a specific kind of science education in the circle of Muslim science educators. I will not investigate how this new form of science education is to be defined, whether it is postmodernist science education (Good and Shymansky, 2001) or the result of a conceptual change in science (Kampourakis and Nehm, 2014). Rather, I will assess the practical outcomes of this ongoing process in Muslim countries, which I call Islamization of science education via constructivism (Taşkın, 2014). As Haidar pointed out in 1999: "The presence of constructivist views can be attributed to religious [Islamic] beliefs. Students' views that scientists cannot see the real thing is consistent with an Islamic understanding that only God (omniscient) knows the real truth."

He also stated that "Although most teachers held a view that looks to be consistent with the constructivist view, this may be attributed to a religious background.". Similar observations can be found in Taşkın (2014). However, Taşkın's (2014, p. 860) judgment that the underlying problem is a "misinterpretation or misuse" of constructivism in retrospect appears unfortunately naïve since it underestimates the problematic effects of constructivism's relativist epistemology.

Interestingly, almost all previously conducted research in Muslim countries shows that Muslim teachers or students generally are against Western-oriented realism. Generally speaking, research participants' points of view overlap with the conceptual elements of a constructivist cultural setting, which is well aligned with reactionary, conservative, and neoliberal beliefs. While constructivism is imported from Western society too, it appears that one feature legitimizes constructivism in the eyes of Muslim scholars: It has to have its foundation in neoliberal and conservative Western groups. I agree with Muslim science educators on one topic, though: there is no war between Islam and Christianity, particularly with regard to science. There is rather a war between progressive and reactionary camps in societies. The coalition between Muslim and Christian reactionary forces is quite visible (Shapiro, 1999).

The terminology used in research papers, which regularly prefer the terms colonization over the term imperialism, has a predetermining effect, too. Muslim science education researchers have not put their focus on oppressed groups and classes in educational settings, such as women or the poor. It is also for this reason that 
they have failed to offer commitments of the Enlightenment to their own citizens. Unfortunately, both liberal Muslim educators who live in Western countries and liberal Western educators pursue an agenda that would drive Muslim societies to social drawbacks.

\section{New Type of Science Educators and Their Foundation}

In the political ambiance outlined above, a new type of scientist emerges. I shall not attempt to subsume all science educators under one category. However, Bourdieu's concept of Cultural Capital (CC) is helpful in outlining the situation, and thereby understanding the actions, of Muslim science educators in the $21^{\text {st }}$ century. To understand their specific kind of CC, we need to ask the following questions: What kind of connections should researchers have to get grants? Can they feel free to approach controversial issues? For instance, are there any problems concerning the science education curriculum and biology textbooks with respect to teaching evolution? What are the policies regarding science in Muslim countries? As far as I see, Muslim science educators do not feel comfortable to ask such questions. If someone asked this kind of question, s/he can be presented as conservative by their Western colleagues.

Thus, science educators, apart from some exceptions (see Muğaloğlu, 2018; Peker, 2018), have been rather unwilling to criticize biology curricula, as for example Asghar et al. (2014), who say that "...we do not intend to evaluate or judge the overall quality of science curricula...". Similar quotes can be found in BouJaoude and coworkers (2011), too. Even though some criticism regarding biology curricula, specifically the representation of evolution, in Muslim countries can be found in literature, these articles do not bear the names of Muslim authors. It should be noted again that the present paper mostly focusses on papers based in research that was conducted in Muslim countries and that were published in the most prestigious journals by authors with roots in Muslim cultures and/or a high degree of familiarity with these cultures. Given this background, Kampourakis and Nehm should be asked about what is behind the conceptual change in science. Further questions emerge: What are the responsibilities of a scientist? How is data collected? For Günal (2016), collecting data is not a central issue when indeed it is a major factor in the quality of research.

These questions may be regarded as inappropriately critical because even in the U.S. political pressure on academics was quite observable at the beginning of the 2000s (Good, 2003). If the situation in the U.S. is considered bad, then it is to be concluded that academic freedom does not exist in many countries, particularly in Muslim countries. This conclusion can be supported by data from the Foundation of Cross-Cultural Research Projects and Topics. Jubas (2012) disseminates her own academic experiences at Canadian universities which are considered to enjoy one of the highest degrees of academic freedom in the world. One of the topics which Jubas pointed out is "academic freedom and neoliberal constraints". The paper includes observations about how granting procedures function and funding is directed by, and based on, the benefits of the research for private organization. In addition, Jubas stresses governmental priority areas. This tendency can be seen all over the world. Indeed, Jubas states the particular agencies' names in her article. Interestingly, most of the previously conducted research in Muslim countries has been supported by a certain group of foundations. In applying for research grants, researchers need to outline every step of their proposed project, including the theoretical framework they intend to use. As Table 1 shows, almost all the theoretical frameworks of studies on evolution are based on constructivism, and/or constructivism's keywords such as multiculturalism, cultural setting, democratic education, border crossing, and respecting different thoughts, are used widely. The research proposals directly assert that all results will be evaluated in the context of constructivism.

Table I

Some previously conducted studies regarding teaching evolution

\begin{tabular}{llllll}
\hline Researcher(s) & Methodology & $\begin{array}{l}\text { Conducted } \\
\text { country }\end{array}$ & $\begin{array}{l}\text { Published } \\
\text { Journal (Year) }\end{array}$ & $\begin{array}{l}\text { Suggestions } \\
\text { \&Theoretical } \\
\text { framework }\end{array}$ & $\begin{array}{l}\text { Financial } \\
\text { foundation }\end{array}$ \\
\hline $\begin{array}{l}\text { Hokayem, \& } \\
\text { BouJaoude }\end{array}$ & Qualitative & Lebanon & JRST-2008 & $\begin{array}{l}\text { Students' personal } \\
\text { beliefs \&cultural milieu } \\
\text { (constructivism) }\end{array}$ & Unavailable \\
\hline Ashgar, Wiles, \& & Qualitative & Some Pakistani & JBE-2010 & Students' personal & SSHRC-Canada \\
\hline
\end{tabular}




\begin{tabular}{|c|c|c|c|c|c|}
\hline Alters & & $\begin{array}{l}\text { private school } \\
\text { biology textbooks }\end{array}$ & & beliefs (constructivism) & \\
\hline $\begin{array}{l}\text { BouJaoude, } \\
\text { Ashgar,Wiles, } \\
\text { Jaber,Sarieddine, \& } \\
\text { Alters }\end{array}$ & Qualitative & Lebanon & IJSE-2011 & Alternative conceptions & SSHRC-Canada \\
\hline $\begin{array}{l}\text { BouJaoude, Wiles, } \\
\text { Ashgar, \& Alters }\end{array}$ & $\begin{array}{l}\text { Quantitative \& } \\
\text { Qualitative }\end{array}$ & Egypt\& Lebanon & S\&E-2011 & Misconception & SSHRC-Canada \\
\hline Asghar & Qualitative & Canada\& Pakistan & EEO-2013 & Content knowledge & SSHRC-Canada \\
\hline $\begin{array}{l}\text { Asghar, Hameed \& } \\
\text { Farahani }\end{array}$ & Qualitative & $\begin{array}{l}\text { Egypt, Malaysia, } \\
\text { Syria, Turkey, \& } \\
\text { Pakistan } \\
\end{array}$ & $\begin{array}{l}\text { Religion\& } \\
\text { Education-2014 }\end{array}$ & $\begin{array}{l}\text { Textbook content } \\
\text { analysis }\end{array}$ & Unavailable \\
\hline Hameed & NA & NA & PUS-2015 & NA & NSF-USA \\
\hline $\begin{array}{l}\text { Deniz, Donnelly, \& } \\
\text { Y1lmaz }\end{array}$ & Quantitative & Turkey & JRST-2008 & $\begin{array}{l}\text { Conceptual Ecology } \\
\text { Stopping mechanistic } \\
\text { teaching } \\
\text { (constructivism) }\end{array}$ & Unavailable \\
\hline $\begin{array}{l}\text { Deniz, Çetin, \& } \\
\text { Yılmaz }\end{array}$ & Quantitative & Turkey & NCSE-2011 & Constructivism & Unavailable \\
\hline $\begin{array}{l}\text { Donnelly, } \\
\text { Kazempour, \& } \\
\text { Amirshokoohi } \\
\end{array}$ & $\begin{array}{l}\text { Quantitative \& } \\
\text { Qualitative }\end{array}$ & U.S.A. & RISE-2009 & $\begin{array}{l}\text { Border crossing } \\
\text { (constructivism) }\end{array}$ & Unavailable \\
\hline Mansour & Qualitative & Egypt & IJSE-2008 & $\begin{array}{l}\text { Social-cultural } \\
\text { constructivist Personal } \\
\text { religious beliefs (PRB) }\end{array}$ & Unavailable \\
\hline Mansour & Qualitative & Egypt & CSSE-2010 & $\begin{array}{l}\text { PRB- partnership- } \\
\text { different understanding }\end{array}$ & Unavailable \\
\hline Mansour & Qualitative & Egypt & SE- 2011 & $\begin{array}{l}\text { Ijtihad- distrust secular } \\
\text { Western science } \\
\text { (constructivism) }\end{array}$ & Unavailable \\
\hline $\begin{array}{l}\text { Deniz, Cömert, \& } \\
\text { Kence }\end{array}$ & Quantitative & Turkey & S\&E-2010 & Scientific treatment & No fund \\
\hline Taşkın & Qualitative & Turkey & EEO-2011 & Scientific treatment & No fund \\
\hline Taşkın & $\begin{array}{l}\text { Quantitative \& } \\
\text { Qualitative }\end{array}$ & Turkey & JBE- 2013 & $\begin{array}{l}\text { Political affiliation, } \\
\text { injected constructivism, } \\
\text { religious pressure }\end{array}$ & No fund \\
\hline Taşkın & Qualitative & U.S.A. & CSSE-2014 & $\begin{array}{l}\text { Islamization of science } \\
\text { education via } \\
\text { constructivism }\end{array}$ & No fund \\
\hline $\begin{array}{l}\text { Aroua, Coquide, \& } \\
\text { Abbes }\end{array}$ & Qualitative & Tunisia & EEO- 2010 & $\begin{array}{l}\text { Epistemological } \\
\text { approach of NOS }\end{array}$ & Unavailable \\
\hline
\end{tabular}

There appear to be no projects on teaching biological diversity in the context of evolution in any Muslim country nor does it seem to be likely to find support for this kind of project in the Middle East. Rasmus Nielsen (2016), from Berkeley Integrative Biology Department, critically asks similar question and follows up saying:

\footnotetext{
“...Notice that the rejection includes a statement that the Society wishes to support occasional meetings in '...Africa, South America, India, and China...' - a list of regions that explicitly does not include the Middle East. The reason given is that the society '...h has widespread concerns about the political stability and safety in the region'. So, we choose not to support our evolutionary biology colleagues in the Middle East because of safety concerns? If I am to take this literally, I can only interpret it as an extreme form of cowardice. But perhaps it is really not fear but other concerns that really underlie this decision. I will refrain from second-guessing the council's decision..." (Nielsen, 2016, February 25)
}

While Nehm and Kampourakis (2014) stress that teaching macro-evolution is a necessity and Padian (2010) presents practical reasons for teaching macro-evolution should at K-12 and college level, constructivist science educators have kept their silence. Against this background, it makes sense that Lesh and some others would not let me interview them about how to teach evolution in mosques -after many years- makes sense right now. The predetermined framework of research based on negotiation within the cultural setting does not allow researchers to offer any suggestion based on themes of the Enlightenment. It should also be pointed out that research institutes, particularly in the U.S., need students from Muslim countries to survive financially. Even though Saudi Arabia has financial problems, 60.000 Saudi students enroll at U.S. universities. This makes 
Saudi Arabia the $4^{\text {th }}$ biggest supporter country of higher education in the U.S. (Kottasova, 2016).

In 1968, Houser reported on biology education in Turkey. He mentioned drawbacks such as overcrowded classes, financial problems in the educational setting, etc., but he did not indicate that the topic of evolution was omitted from curricula or underrepresented. However, in the past 50 years since Houser's report, the power of reactionary movement and their influences over science curricula has become quite visible (Peker \& Taşkın, 2018). As mentioned before, Peker and coworkers (2010) show that except for a few metropolitan universities in Turkey evolution has not properly been taught for the last 30 years. As they mention in their paper, whether or not the TOE is taught depends on instructors' individual decisions. Taşkın's (2013, p. 205) research results also support this finding. One of the research participants said "...You should pose the question to our teachers why did not we learn the TOE...". After reviewing the articles about teaching evolution in Turkey, Muğaloğlu (2018) indicated that the topic of evolution is inadequately covered in the national science education curriculum and that learning outcomes are poor; in some cases, the topic is not covered at all. Contrary to the existing practice, she is in favor of teaching evolution. Yet, with the latest curricular reforms (Milli Eğitim Bakanlığ [MEB], 2018a, 2018b), "evolution" as a word has been officially removed from science and biology education curriculum in Turkey (Muğaloğlu, 2018).

Collecting data is just a technical issue. However, data should make sense for the public good. Interestingly, Fouad (2016) works on a thesis regarding Muslim American undergraduate students' view on evolution. It is difficult to understand why Fouad attributes equal importance to Harun Yahya and Richard Dawkins. Does Fouad think that these two people are of equal importance? While Dawkins' books can be found in most libraries, Yahya's one cannot. Is this really in the interest of the public good to attribute the same weight to both authors?

Even I have abstained from using popular measurement tests to support my arguments, I would like to point to the PISA test scores and social progress indices; they make quite clear where Muslim countries stand. If one claims that all indices are based on Western values, then one also should ask oneself why Muslim science educators and researchers have borrowed constructivist philosophy from their Western partners. It appears that those are not purely pragmatist choices.

\section{Conclusions}

To sum up, constructivist epistemology is to some a useful tool to convert Muslim groups to buttress conservative and reactionary ideas and unscientific thought in Muslim groups and to atomize Muslim societies. Going in the same direction, studies on teaching evolution in Muslim countries mostly suggest social negotiation under the watchful eye and exposed to the pressure of conservative governments, NGOs, and religious groups ${ }^{5}$. At the same time, Muslim science educators receive support both financially and intellectually from Western liberal academic circles. Among those who promote the above-mentioned negotiations are also Western institutes. For instance, the Faraday Institute of Science and Religion has organized a meeting to mediate between different groups. One member of the Western audience suggested to scientists to agree with some religious NGOs about evolution. Even though Francisco Ayala was one of the keynote guest speakers and the closing session was recorded, it was not broadcasted (Faraday Institute Newsletter, 2009). Is this what is called negotiation?

Speaking of legitimization and negotiation, when Muslim science educators would like to justify their thoughts, they use Western sources such as National Science Education Standards. Indeed, they take their lines to heart, such as: Scientific ideas are tentative and open to change (NRC, 1996). Such statements serve many conservative and liberal educators as a lever to distort science (Muğaloğlu, 2014; Muğaloğlu \& Erduran 2012). Even though the final version of the NRC dismisses the term postmodernist, Matthews (2000) says it has not been deleted but only relocated. When similar statements are deemed as a part of multicultural science education and imposed by Western scientists, Muslim science educators have gratefully taken them up to be 
nurtured both financially with grants and politically in the public arena.

This codependence is not limited to liberal Christians. It includes non-secular Orthodox Christian conservatives too. Shapiro (1999) wisely summarizes, based on a document of the Institute for Creation Research (ICR): "[T]he movement in Turkey is a 'literalist' translation of Christian creationism a la Henry Morris and ICR .... Islam, Christianity, and Judaism share so many common religious ideas." (p. 15). In light of Shapiro's argument, if there indeed was a clash of civilizations, as Huntington (1993) stated, it does not take place in the area of science education. Contrary to Huntington's belief, there is an agreement between the perceptions of some Muslim and Christian Science educators to distort science into pseudo-science based on religion.

In any case, science education in Muslim countries faces two options. The first one is to vanish, driven away by neoliberal and conservative politics; the second one is to redesign themselves based on a secular foundation of science. What the former one offers can be seen in a paper by Dangor (2005) entitled Islamization of disciplines: Towards an indigenous educational system. Needless to say, all claims in the paper are based on the constructivist approach, which, in the final analysis, is pro-neoliberal and centered in the West. Even though Dangor's suggestions regard social sciences, he also suggests a methodological process of construction in research based on Alfred Louch's claims. At the same time, Dangor also refers to Max Weber in the context of verstehen and gives credit to interpretive understanding. I do not expect Dangor to offer the Muslim world class consciousness through Marxism. However, Dangor as other pro-constructivists, works toward atomizing society and stresses individuality, thereby ironically hiding all those factors that account for individuals' opportunities and development. Certainly, if indeed there is Christian Science, Buddhist science, etc., then Dangor has a right to serve to a mass audience the concoction of an Islamic science, as Muzaffar Iqbal has suggested. As mentioned before, religious motives combined with constructivism and labeled multicultural education, value education, and respecting differences in thought are a quite useful political tool.

For instance, Moudouros (2014) draws a detailed picture in an article entitled The Harmonization of Islam with the Neoliberal Transformation: The case of Turkey. He explains the economic and social transformation which begun with the 1980 military coup and has continued driven by right wing parties. In Muslim countries, this social transformation takes place in the context of Neoliberalism and is harmonized with Islam in educational settings. Indeed, constructivist pedagogy takes part in this. It inevitably distorts educational settings and controversial issues such as teaching evolution. Çakmak (2009) wisely explains how pro-Islamic public education has spread in Turkey via The Imam-Hatip schools. Çakmak states that "...Turkey might in the short run be dragged towards a quagmire..." (p. 843). More than 30 years ago, Kritsky (1984) described teaching evolution in Egyptian colleges in The American Biology Teacher and showed how clergy dominated over science education.

Certainly, the distortion and transformation of educational settings has not been spared from changes in society. Changes can be progressive or reactionary. Unfortunately, the cultural shift in Muslim societies has been the latter (cf. Abramson and Inglehart, 1995).

The present article's aim was not to denigrate the belief system of Muslim peoples, even if it is usually opposed to the TOE. Rather, the goal was to point Muslim science educators toward their responsibilities, remind them of their vital role to emancipate society instead of allowing oppressed and underrepresented Muslims to be taken advantage of by the ruling class. Disadvantaged Muslim peoples need science education, not pseudoscience based on myths. This is in the long run the only way to live in peace. Considering the power of religion in Muslim societies, the Marx's explanation of the power of spirituality comes to mind. He explained it as a symptom of illness, namely illiteracy. The new, rising conservative bourgeois 'Nouveau riche' in Muslim countries are not different from the former allegedly secular bourgeoisie. Both do not differ in terms of using religion and nationalism, though features, tones, and motives have changed.

Finally, I wish to return to Tony Blair, whom I mentioned at the beginning of this paper. William's (2008) criticism regarding Mr. Blair should not be considered as political. However, I politically criticize Mr. Blair. It is known that social democrat parties have incorporated neoliberal politics and policies, including the 
privatization of education, of the health care system, etc. At least, Mr. Blair should have defended secular scientific education. Alexander and Welzel (2017) write "... Indeed, prominent parties, like New Labor in the UK, ceased to advocate economic policies that meet the lower class...". Maybe at this point, Foa and Mounk's (2017) thoughts should be considered at least for Muslim countries: Democracy, if there was, is in danger.

Contrary to other Muslim science educators' criticism of Eurocentric secular progressive science educators, I intentionally directed my criticism towards Western science educators who are proponents of illstructured constructivism. They may continue as long as they would like on their own track criticizing and undermining science - after all, this appears to have little actual impact on science in Western countries. However, they need to stop imposing pseudoscience on Muslim societies under the pretext of constructivism because this is hypocritical and damaging to these societies. McCarthy argued against a watered-down and distorted concept of science because "multi-science... is actually a particularly detrimental form of cryptoracism" (2018, p.110). Thus, crypto-racism is making forays into science education through an irresponsible use of constructivism. This should be taken into consideration by all science educators focusing on science education in Muslim societies, and not to the least degree by Western science educators.

\section{Declarations}

Acknowledgements: I kindly present my sincere appreciation equally to Dr. Michael R. Matthews' immeasurable support and Dr. Karl-Heinz Maurer's suggestions and language editing.

Authors' contributions: Not applicable.

Competing interests: The author declares that he has no competing interests.

Funding: Not applicable.

\section{References}

Abramson, P. R., \& Inglehart, R. (1995). Value change in global perspective. Ann Arbor, MI: University of Michigan Press.

Aikenhead, G. S. (1996). Cultural assimilation in science classrooms: Border crossings and other solutions. Studies in Science Education, 27(1),1-52.

Aikenhead, G., \& Ogawa, M. (2007). Indigenous knowledge and science revisited. Cultural Studies in Science Education, 2(3), 539 - 620. doi: 10.1007/s11422-007-9067-8

Alexander, A. C., \& Welzel, C. (2017). The myth of deconsolidation: Rising liberalism and the populist reaction (No. 10). ILE Working Paper Series.

Al-Hayani, F. A. (2005). Islam and science: Contradiction or concordance. Journal of Religion \& Science, 40(3), 565-576. doi:10.1111/j.1467-9744.2005.00688.x

Alters, B J. (1997). Whose nature of science? Journal of Research in Science Teaching, 34(1), 39-55. doi: 10.1002/(SICI)1098-2736(199701)34:1<39::AID-TEA4>3.0.CO;2-P

Anonymous. (2009). Turkey censors evolution. Nature, 458 (7236), 259. doi: 10.1038/458259a

Aroua, S., Coquide, M., \& Abbes, S. (2010). Overcoming the effect of the socio-cultural context: Impact of teaching evolution in Tunisia. Evolution Education \& Outreach, 2(3), 474-478. doi:10.1007/s12052-009-0129-0

Asghar, A. (2013). Canadian and Pakistani science teachers' perceptions of evolutionary science and evolution education. Evolution Education \& Outreach, 6(10), 1-12. doi:10.1186/1936-6434-6-10

Asghar, A., Hameed, S., \& Farahani, N. (2014). Evolution in biology textbooks: A comparative analysis of 5 Muslim countries. Religion \& Education, 41(1), 1-15. doi:10.1080/15507394.2014.855081

Borgerding, L. A., Deniz, H., \& Anderson, E. S. (2017). Evolution acceptance and epistemological beliefs of college biology students. Journal of Research in Science Teaching, 54(4), 493-519. doi:10.1002/tea.21374 
BouJaoude, S., Asghar, A., Wiles, J. R., Jaber, L., Sarieddine, D., \& Alters, B. (2011). Biology professors' and teachers' positions regarding Biological Evolution and Evolution Education in Middle Eastern Society. International Journal of Science Education, 33(7), 979-1000. doi:10.1080/09500693.2010.489124

BouJaoude, S., Wiles, J. R., Asghar, A., \& Alters, B. (2011). Muslim Egyptian and Lebanese students' conceptions of Biological Evolution. Science \& Education, 20(9) 895-915. doi:10.1007/s11191-011-9345-4

Bowering, G. (2013). Princeton Encyclopedia of Islamic Political Thought. Oxford: Princeton University Press.

Castéra, J., \& Clément, P. (2014). Teachers' conceptions about the genetic determinism of human behaviour: A survey in 23 countries. Science \& Education, 23(2), 417-443.

Clément, P. (2015). Muslim teachers' conceptions of evolution in several countries. Public Understanding of Science. 24(4), 400-421. doi:10.1007/s11191-012-9494-0

Cobern, W., \& Aikenhead, G. (1998). Cultural aspects of learning science. In B. Fraser \& K.G. Tobin (Eds.), International handbook of science education, part 2 (pp. 39-52). Dordrecht, The Netherlands: Kluwer Academic Publishers.

Çakmak, D. (2009). Pro-Islamic public education in Turkey: The Imam-Hatip schools. Middle Eastern Studies, 45(5), 826-846. doi:10.1080/00263200903135596

Dangor, S. (2005). Islamization of disciplines: Towards an indigenous educational system. Educational Philosophy \& Theory, 37, 519-531. doi:10.1111/j.1469-5812.2005.00138.x

Deniz, H., Donnelly, L. A., \& Yllmaz, I. (2008). Exploring the factors related to acceptance of evolutionary theory among Turkish pre-service biology teachers: toward a more informative conceptual ecology for biological evolution. Journal of Research in Science Teaching, 45(4), 420-443. doi:10.1002/tea.20223

Deniz, H., Çetin, F., \& Yllmaz, I. (2011). Examining the relationships among acceptance of evolution, religiosity, and teaching preference for evolution in Turkish preservice biology teachers. Reports of the National Center for Science Education, 31(4).

Develay, M. (1989). A propos de la transposition didactique en sciences biologiques. In G. Arsac, M. Develay, \& A. Tiberghien, (Eds.), La Transposition didactique: En mathematiques, en physique, en biologie (pp. 59-86). Lyon: LIRDIS.

Donnelly, L. A., Kazempour, M., \& Amirshokoohi, A. (2009). High school students' perceptions of evolution instruction: Acceptance and evolution learning experiences. Research in Science Education, 39(5), 643-660. doi:10.1007/s11165-008-9097-6

Dowd, R. A. (2003, August). Christianity, Islam, and political culture: Lessons from Sub-Saharan African in comparative perspective. In paper presented at the annual meeting of the American Political Science Association, Philadelphia.

Edis, T., \& BouJaoude, S. (2014). Rejecting Materialism: Responses to Modern Science in the Muslim Middle East. In M. Matthews (Ed.), International Handbook of Research in History, Philosophy and Science Teaching (pp. 1663-1690). Springer: Netherlands.

Faraday Institute Newsletter (2009, May). Retrieved from https://www.faraday.stedmunds.cam.ac.uk/News.php?Mode=Single_Newsletter\&ID=50

Foa, R. S., \& Mounk, Y. (2017). The signs of deconsolidation. Journal of Democracy, 28(1), 5-15.

Fouad, K, E. (2016). American Muslim undergraduates' views on evolution (Unpublished doctoral thesis). Bloomington: IN.

Gilbert J. K., \& Watts D. M. (1983). Concepts, misconceptions \& alternative conceptions: Changing perspectives in science education. Studies in Science Education, 10(1) 61-98. doi:10.1080/03057268308559905

Good, R. \& Shymansky, J. (2001). Nature-of-science literacy in benchmarks and standards: Post- 
modern/relativist or modern/realist? In F. Bevilacqua, E. Giannetto, \& M. R. Matthews, (Eds.), Science and culture: The contribution of history and philosophy of science (pp. 53-65). Boston: Kluwer Academic Publishers.

Good R. (2003). Evolution and creationism: One long argument. The American Biology Teacher, 65(7), 512-516. doi:10.2307/4451550

Gregory T. R. (2008). Evolution as fact, theory, and path. Evolution Education \& Outreach, 1(1), 46-52. doi:10.1007/s12052-007-0001-z

Guessoum, N. (2008). The Qur'an, science, and the (related) contemporary Muslim discourse. Zygon, 43(2), 411-432. doi:10.1111/j.1467-9744.2008.00925.x

Günal, I. (2016, September, 18). Diyalektiksiz materyalizm (Materialism without Dialectic). Retrieved from http://haber.sol.org.tr/blog/bilimin-izleri/izge-gunal/diyalektiksiz-materyalizm-169378.

Haidar, H. A. (1999). Emirates pre-service and in-service teachers' views about the nature of science. International Journal of Science Education, 21(8), 807-822. doi:10.1080/095006999290309

Hallaq, W. B. (1986). On the origins of controversy about the existences of mujtahids and the gate of ijtihad. Studia Islamica, 63(1), 129-141.

Halliday, F. (2002). Two hours that shook the World: September 11, 2001. Causes and consequences. London: Saqi Books.

Hameed, S. (2015). Making sense of Islamic creationism in Europe. Public Understanding of Science, 24(4), 388399. doi:10.1177/0963662514555055

Herron, D. (2008). Advice to my intellectual grandchildren. Journal of Chemical Education, 85(1), 24-32. doi:10.1021/ed085p24

Hokayem, H., \& BouJaoude, S. (2008). College students' perceptions of the theory of evolution. Journal of Research in Science Teaching, 45(4), 395-419. doi:10.1002/tea.20233

Houser, W. V. (1968). Biology education in Turkey. The American Biology Teacher, 30(1), 31-35. doi:10.2307/4441930

Huntington, S. P. (1993). The clash of civilizations? Foreign Affairs, 75(3), 22-49.

Irzık, G. (2001). Back to basics: A philosophical critique of constructivism. Studies in Philosophy and Education, 20(2), 157-175. doi:10.1007/978-1-349-62965-7_6

Jenkins, E. W. (2001). Constructivism in school science education: Powerful model or the most dangerous intellectual tendency? In F. Bevilacqua, E. Giannetto, \& M. R. Matthews (Eds.), Science education and culture: The contribution of history and philosophy of science (pp. 153-164). London: Kluwer Academic Publishers.

Jubas, K. (2012). On being a new academic in the new academy: Impacts of neoliberalism on work and life of a junior faculty member. Workplace, 21(1), 5-35.

Kahvecioglu, A. (2012, May 2). Yaratilis ve evrim kapışması (Creationism and evolution fight). Retrieved from http://www.milliyet.com.tr/yaratilis-ve-evrim-kapismasi-gundem-1535072/

Kampourakis, K., \& Nehm, R, H. (2014). History of philosophy of science and the teaching evolution: Students' conceptions and explanations. In Matthews M. R. (Ed.), International handbook of research in history, philosophy and science teaching (pp. 377-399). Netherlands: Springer.

Kottasova, I. (2016, February 9). Saudi Arabia cuts funding for students abroad. Retrieved from http://money.cnn.com/2016/02/09/news/saudi-arabia-students-overseas/

Kritsky, G. (1984). Teaching evolution in Islamic country. The American Biology Teacher, 46(5), 266-271. doi:10.2307/4447838

Lederman, N. G. (1995). Suchting on the nature of scientific thought: Are we anchoring curricula in quicksand? 
Science E Education, 4(4) 371-377. doi:10.1007/BF00487758

Mahner, M., \& Bunge, M. (1996). Is religious education compatible with science education? Science $\mathcal{E}$ Education, 5 (2), 102-123. doi:10.1007/BF00428612

Mansour, N. (2008). The experiences and personal religious beliefs of Egyptian science teachers as a framework for understanding the shaping and reshaping of their beliefs and practices about science-technologysociety (STS). International Journal of Science Education, 30(12), 1605-1634. doi:10.1080/09500690701463303

Mansour, N. (2010). Science teachers' interpretations of Islamic culture related to science education versus the Islamic epistemology and ontology of science. Cultural Studies of Science Education, 5(1), 127-140. doi:10.1007/s11422-009-9214-5

Mansour, N. (2011). Science teachers' views of science and religion vs. the Islamic perspective: Conflicting or compatible. Science Education, 95(2), 281-309. doi:10.1002/sce.20418

Matthews, M. R. (2000). Time for science education: how teaching the history and philosophy of pendulum motion can contribute to science literacy. New York: Plenum Press.

Matthews, M. R. (2015). Reflections of 25 years of journal editorship. Science E Education, 24(5-6), 749-805. doi:/10.1007/s11191-015-9764-8

Matthews, M. R. (2018). History, Philosophy, and Science Teaching: New perspectives. Cham, Switzerland: Springer.

Matthews, M. R. (2021). Philosophical problems with constructivism: Some considerations for studentcentered learning and instruction. In Sabine Hoidn \& Manja Klemenčič (Eds.), The Routledge International Handbook of Student-Centered Learning and Teaching in Higher Education (pp. 47-64). New York: Routledge. (Upcoming)

McCarthy, C.L. (2018). Cultural studies of science education: An appraisal. In Matthews M. R. (Ed.), History, Philosophy, and Science Teaching: New perspectives (pp. 99-138). Cham, Switzerland: Springer.

Milli Eğitim Bakanlığı. (2018a). Fen bilimleri dersi öğretim programı (Science education curriculum). Talim ve Terbiye Kurulu, Milli Eğitim Bakanlığı. Ankara, Turkey.

Milli Eğitim Bakanlığı. (2018b). Ortaöğretim biyoloji dersi programı (High school biology education curriculum). Talim ve Terbiye Kurulu, Milli Eğitim Bakanlığı. Ankara, Turkey.

Moudouros, N. (2014). The harmonization of Islam with the neoliberal transformation: The case of Turkey. Globalization, 11(6), 843-857. doi:10.1080/14747731.2014.904157

Muğaloğlu, E. Z. (2014). The problem of pseudoscience in science education and implications of constructivist pedagogy. Science \& Education, 23(4), 829-842. doi:10.1007/s11191-013-9670-x

Muğaloğlu, E. Z. (2017). Bilim eğitiminde yapılandırmacılık yaklaşıma eleştirel bakış (Critical view of constructivist approach in science education). In Ö. Taşkın (Ed.), Fen eğitiminde güncel konular (Current issues in science education) (pp. 8-22). Ankara: Pegam Akademi.

Muğaloğlu E. Z. (2018). An Insight into Evolution Education in Turkey. In Deniz H., \& Borgerding L. (Eds.), Evolution Education Around the Globe (pp. 263-279). Cham, Switzerland: Springer.

Muğaloğlu, E. Z. \& Erduran, S. (2012). Prospective science teachers' appreciation of science: The case of evolution vs. intelligent design. In C. Bruguière, A. Tiberghien, \& P. Clément (Eds.), E-Book Proceedings of the ESERA 2011 Conference: Science learning and Citizenship. Part 5 (L. Maurines \& A. Redfors), (pp. 100-105). Lyon, France: European Science Education Research Association. ISBN: 978-9963-700-44-8

Nanda, M. (2003). Prophets Facing Backward. Postmodern Critiques of Science and Hindu Nationalism in India. New Brunswick, NJ: Rutgers University Press.

National Research Council. (1996). The national science education standards. Washington, DC: National Academy 
Press.

National Research Council. (1998). Teaching about evolution and the nature of science. Washington, DC: National Academy Press.

Nehm, R, H., \& Kampourakis, K. (2014). History and philosophy of science and the teaching of macroevolution. In Matthews M. R. (Ed.), International Handbook of Research in History, Philosophy and Science Teaching (pp. 401-421). Netherlands: Springer.

Nielsen, R. (2016, February 25). Teaching evolution in the Middle East. Retrieved from http://www.nielsenlab.org/2016/02/teaching-evolution-in-the-middle-east/

Padian, K. (2010). How to win the evolution war: Teach macroevolution! Evolution Education E Outreach, 3(3), 206-214. doi:10.1007/s12052-010-0213-5

Peker, D. (2018). Creationism in Turkish school curricula: The shadow of anti-scientism. Revue Internationale d'education de Sevres, 77 (April), 93-101. doi:10.4000/ries.6144

Peker, D., Cömert, G. G., \& Kence, A. (2010). Three decades of Anti-Evolution campaign and its results: Turkish undergraduates' acceptance and understanding of the Biological Evolution Theory. Science E Education, 19(6-8), 739-755. doi:10.1007/s11191-009-9199-1

Peker, D., \& Taşkın, Ö. (2018). The Enlightenment tradition and science education in Turkey. In Matthews M. R. (Ed.), History, Philosophy, and Science Teaching: New perspectives (pp. 67-97). Cham, Switzerland: Springer.

Phillips, D. C. (1995). The good, the bad, and the ugly: The many faces of constructivism. Educational Researcher, $24(7), 5-12$.

Sak, A. (2010, October 9). Iciniz rahat olsun (Consider it is done). Retrieved from http://www.turkishnews.com/tr/content/2010/10/09/iciniz-rahat-olsun/

Shapiro, A. M. (1999). Fundamentalist bedfellows: Political creationism in Turkey. Reports of the National Center for Science Education, 19 (6),15-17.

Taşkın, Ö. (2011). Can willingness and hands-on work together? Teaching biological evolution and dealing with barriers. Evolution Education \& Outreach, 4(3), 467-77. doi:10.1007/s12052-011-0341-6

Taşkın, Ö. (2013). Pre-service science teachers' acceptance of biological evolution in Turkey. Journal of Biological Education 47(4), 200-207. doi:10.1080/00219266.2013.788540

Taşkın, Ö. (2014). An exploratory examination of Islamic values in science education: Islamization of science teaching and learning via constructivism. Cultural Studies of Science Education 9(4), 855-875. doi:10.1007/s11422-013-9553-0

White, R. D. (1980). Education in bourgeoisie society: A matter of common sense. Interchange, 11(1) 47-60.

Williams, D. J. (2008). Creationist teaching in school science: A UK perspective. Evolution Education $\mathcal{E}$ Outreach, 1(1), 87-95. doi:10.1007/s12052-007-0006-7

von Glasersfeld, E. (1995). Radical constructivism: A way of knowing and learning. London: Falmer.

Yılmaz, İ., \& Uzunoğlu, S. (1995). Alternatif biyolojiye doğru. İzmir, Turkey: Nil Yayınevi. ISBN: 9757744360.

Yılmaz, İ. (2008). Evolution: Science or ideology. New Jersey: Tughra Books. ISBN: 978-1-59784-118-4

\section{Suggested Readings}

Hoodbhoy, P. (1985). Ideological problems for science in Pakistan. In A. Khan (Ed.), Islam, politics and the state (pp. 178-191). London: Zed Books.

Hoodbhoy, P. (1991). Islam and Science. London: Zed Books. 